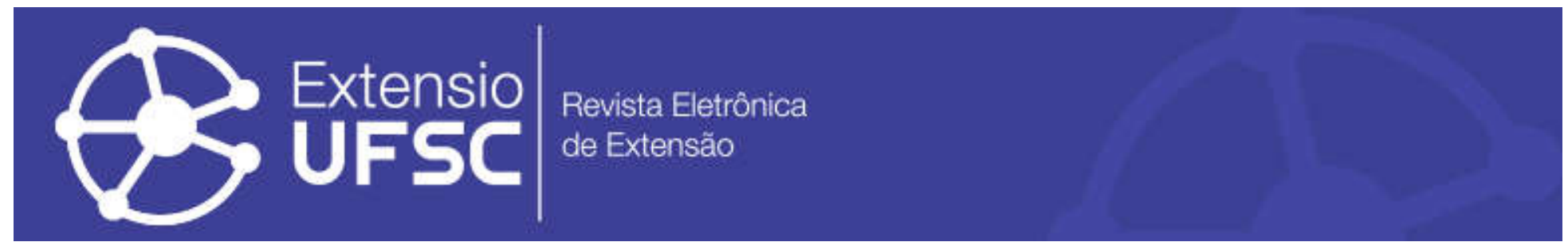

\title{
GASTROESOPHAGEAL REFLUX DISEASE IN PATIENTS WITH DEVELOPMENTAL DISABILITIES
}

\author{
Lia Silva de Castilho \\ Universidade Federal de Minas Gerais \\ liasilvacastilho@gmail.com \\ Camila de Menezes Rampi \\ Universidade Federal de Minas Gerais \\ camilarampi@hotmail.com \\ Alex Junio Silva Cruz \\ Universidade Federal de Minas Gerais \\ junio.alex@hotmail.com
}

Frederico Santos Lages Universidade Federal de Minas Gerais fredlages@hotmail.com

Daniel Marques Leão Universidade Federal de Minas Gerais dandanleao@gmail.com

Mauro Henrique Nogueira Guimarães Abreu Universidade Federal de Minas Gerais maurohenriqueabreu@gmail.com

\begin{abstract}
Objective: To investigate the prevalence and factors associate to gastroesophageal reflux disease (GERD) in individuals 0 to 33 years with developmental disability. Methods: In all 628 dental records were analyzed. The analyzed GERD cases were recorded based on reports from parents and caregivers. The variables with $\mathrm{p}$ value $<0.25$ in the bivariate analysis were included in the multiple logistic regression models. The variables with $\mathrm{p}$ value $<0.05$ were considered significant and included in the final multiple logistic regression model. Results: Be a mouth-breather user of "other medication", and a past history of seizures were factors associated with GERD in patients with developmental disabilities.

Keywords: Cerebral Palsy. Developmental Disabilities. Gastroesophageal Reflux Disease.
\end{abstract}

\section{DOENÇA DO REFLUXO GASTROESOFÁGICO EM PACIENTES COM DEFICIÊNCIAS DO DESENVOLVIMENTO}

\section{Resumo}

Objetivo: Investigar a prevalência e os fatores associados ao refluxo gastroesofágico em indivíduos de 0 a 33 anos de idade com deficiências do desenvolvimento. Métodos: 628 prontuários odontológicos foram analisados. Os casos de refluxo foram anotados baseados nos relatos dos responsáveis. Variáveis com valor de $\mathrm{p}$ menor do que 0.25 foram incluídas no modelo de regressão logística. Variáveis com valor de p menor do que 0.05 foram consideradas como significativas no modelo final. Resultados: ser respirador bucal, usar "outros medicamentos" e ter histórico de convulsões foram fatores associados ao refluxo gastroesofágico entre pacientes com deficiências de desenvolvimento.

Palavras-chave: Paralisia Cerebral. Deficiências de Desenvolvimento. Doença do Refluxo Gastroesofágico.

\section{ENFERMEDAD POR REFLUJO GASTROESOFÁGICO EN PACIENTES CON DISCAPACIDADES DEL DESARROLLO}

\section{Resumen}

Objetivo: investigar la prevalencia y los factores asociados con el reflujo gastroesofágico en individuos de 0 a 33 años con discapacidades del desarrollo. Métodos Se analizaron 628 registros dentales. Los casos de reflujo se observaron según los informes de los responsables. Las variables con un valor de p menor que 0.25 se incluyeron en el modelo de regresión logística. Las variables con un valor $\mathrm{p}$ inferior a 0,05 se consideraron significativas en el modelo final. Resultados: ser un respirador bucal, usar "otros medicamentos" y tener antecedentes de convulsiones fueron factores asociados con el reflujo gastroesofágico en pacientes con discapacidades del desarrollo.

Palabras clave: Parálisis Cerebral. Discapacidades del Desarrollo. La Enfermedad por Reflujo Gastroesofágico. 
Gastroesophageal reflux disease in patients with developmental disabilities

\section{INTRODUCTION}

Patients with developmental disabilities, especially cerebral palsy, are part of the risk group for the development of Gastroesophageal Reflux Disease (GERD) (FURKIM et al., 2003). The muscular alterations present in these patients induce incorrect swallowing while feeding, that can result in tracheal aspiration, having consequences such as chronic tracheal aspiration, recurrent pneumonias, and vomiting. Such changes are associated with bolus control inability, lack of lingual control, and lip seal (FURKIM et al., 2003).Several aspects contribute to gastroesophageal reflux in patients with developmental disabilities, such as esophageal sphincter reduction, delayed gastric emptying, impaired esophageal motility, poor posture, recurrent seizures, scoliosis, and varied drug therapy(TRINICK et al., 2012).

Gastroesophageal reflux disease is often diagnosed late in these patients due to their severe cognitive and communication impairments (GÖSSLER et al., 2007). Thus, parents and caregivers have to interpret the behavior of these individuals that may indicate the symptomatology indicative of pain. The pain that is associated with gastroesophageal reflux leads to a change in the behavior of these patients increasing agitation, involuntary movements, spasms, myoclonus, moaning, crying, and or persistent cough, difficulties to pacify, selfaggressive behavior, sleep disorders, difficulty gaining weight, regurgitation, and hematemesis (GÖSSLER et al., 2007).

Patients with gastroesophageal reflux disease (GERD) may develop nutritional, respiratory, vascular problems and cancer (JIMENEZ et al., 2010; HSU et al., 2016). Besides, they may also have oral problems, such as dental erosion, due to acid bathing the dental surface(ABANTO et al., 2014)and chronic conditions of the throat, such as hoarseness, wounds, chronic laryngitis, difficulty speaking, cough, and granulomas in the vocal cords. Untreated chronic acid regurgitation due to GERD may cause Barrett's esophagus, which is strongly associated with esophageal adenocarcinoma(HUYN et al., 2014). The esophageal epithelium is not able to resist the digestive action of the gastric secretion, which generates a mucosal inflammation and can lead to insults in this epithelium, causing esophagitis, ulceration, induction of esophageal epithelial metaplasia, that may lead to an increased risk of developing adenocarcinoma and esophageal stricture (MENGATTO et al., 2013).

Based onwhat was said above, the dental team considered that they could help the multidisciplinary care team of patients with developmental disabilities to understand what factors are associated with the event. Therefore, the objective of this study is to evaluate the prevalence 
of gastroesophageal reflux and associated factors among individuals with developmental disabilities in an oral health service in Brazil.

The extension project "Dental Care for patients with developmental disabilities"is a partnership between the Faculty of Dentistry of UFMG and this reference center for the rehabilitation of children with neuromotor disabilities, Associação Mineira de Reabilitação AMR, which has been operating since 1998. In addition to dental care for people with developmental disabilities, this extension project carried out several scientific studies to understand the dynamics of oral diseases among this population. In this way, it is possible to help dental surgeons and other areas of medical knowledge to plan and execute treatments that provide the patient with a better quality of life through health promotion.

This is an exploratory study. Our hypothesis is that gastroesophageal reflux disease is associated with the more severe cases of developmental disabilities, use of anticonvulsant drugs, use of asthma medications, use "others medications", involuntary movements, mouth breathing, past history of seizure, current history of seizure, hyperkinesis, sex, age, and sucrose intake.

\section{MATERIALS \& METHODS}

\section{Data source}

This is a cross-sectional observational study that starts with the analysis of dental records inat the oral health service of a reference rehabilitation service in Belo Horizonte, Brazil (Associação Mineira de Reabilitação), which has been working together with the Federal University of Minas Gerais since January 1998 in the extension project "Dental Care for Patients with Developmental Disabilities". Data were collected from medical records from 1998 to March of 2019. Patients who were undergoing dental treatment or oral health maintenance were included in the study. All 628 dental records in this period were analyzed, composed of individuals of both sexes between 0 and 33 years of age. The informed consent of the patients' parents or caregivers were obtained before the beginning of the clinical trial. The study was approved by the Ethics and Research Committee of the Federal University of Minas Gerais - (process number: ETIC 219/03).

The data of the medical record have as main objective the elaboration of a general picture of the patient and to emphasize to the student of dentistry the importance of a comprehensive data collection. Thus, the information collected has as its main function to base the production of a dental treatment plan that addresses the general health and oral health of the patient with developmental disabilities in an integral manner. All data were collected in a standardized way, 
after training of the students, and supervised by teachers with 18 years of experience in the dental approach of these patients.

The database was made by a single researcher (Cohen Kappa $=1.0)$. Data from 50 dental records were collected. After one week, the data from these same records were recorded again. A comparison was made with the data collected in the two collections with $100 \%$ agreement between the data.

\section{Identification of patients with GERD and without GERD}

Gastroesophageal reflux was recorded from reports of the patient's parents and caregivers and medical history. The diagnosis of gastroesophageal reflux was made by medical teams from other institutions and the results were added to the AMR medical records.

\section{Baseline variables}

The covariates collected from the charts were: previous and current history of seizures, age (years), sex, mouth or nasal breathing, involuntary movement, hyperkinesis, medical diagnosis given by the International Code of Diseases (ICD), use of anticonvulsant drugs, use of asthma medications, and use of "other medicines". Data on patient feeding were collected using the second intake index of saccharate foods (BRAÚNA et al., 2016). According to this index, parents and caregivers report the type of food the patient usually eats at each meal. For liquid foods with sucrose, note down the weight "1", and for solid foods with sucrose, the weight "2" is given. If the intake of sucrose is given during the main meals: breakfast, lunch and dinner, the weight is "1", if the food occurs between the main meals, the weight is "2". In this way, for each contact with foods containing sucrose, the consistency multiplies for the moment. Forthe purpose of analysis, feeding and age were considered as continuous variables not being dichotomized.

\section{Statistical analysis}

Data were analyzed statistically from descriptive analysis and multiple logistic regression analysis. The unadjusted odds ratios (OR) with their respective confidence interval (95\% CI) were calculated for each covariate. The variables that obtained values of $p<0.25$ in the unadjusted logistic regression were selected for the multiple logistic regression model. The Forward Wald method was used to estimate adjusted OR (CI95\%). The variables considered significant and maintained in the final multiple logistic regression model were those that obtained values of $\mathrm{p}<0.05$. All analyzes were developed in the SPSS program, version 19.0 
Gastroesophageal reflux disease in patients with developmental disabilities

(SPSS Inc., Chicago, IL, USA). The Hosmer \& Lemeshow test was used to evaluate thesuitability of the model. The standardized residuals and Cook's distances were also checked.

\section{RESULTS}

There was a report of gastroesophageal reflux in 82 patients (13.1\%), out of 620, which is the total number of available patients'records $(n=620)$

Mouth breathing $(\mathrm{p}=0.030)$ and use of central action medication $(\mathrm{p}=0.000)$ were the significant variables in the final model (Table 1). Individuals with a previous history of seizures had a 3.64-fold (95\% CI: 1.73 to 7.63) higher odds of presenting gastro-esophageal reflux; those who consumed the "other medicines" category had 3.89 times (95\% CI: 2.12 to 7.15$)$ more likely to present gastroesophageal reflux. Mouth breathers had a 2.0-fold (95\% CI: 1.06 to 3.74) higher odds of presenting gastroesophageal reflux. The Hosmer \& Lemeshow test showed the adequacy of the model $(\mathrm{p}=0.134)$.Studentized residuals and Cook's distance (values less than 1) demonstrated adequacy of the model.

Table 1 - Associations between gastroesophageal reflux disease and independent variables, Extension Project "Dental Care for Patients with Special Needs". Belo Horizonte, Brazil, 1998-2017

\begin{tabular}{|c|c|c|c|c|c|c|}
\hline Variables & $\begin{array}{l}\text { With } \\
\text { GERD (n } \\
=82)\end{array}$ & $\begin{array}{l}\text { Without } \\
\text { GERD }\end{array}$ & $\begin{array}{c}\text { Crude } \\
\text { OR }(95 \% \\
\text { CI) }\end{array}$ & $\mathrm{P}$ value & $\begin{array}{c}\text { Adjuste } \\
\text { d OR } \\
(95 \% \\
\text { CI })\end{array}$ & $\begin{array}{c}\mathrm{P} \\
\text { Value }\end{array}$ \\
\hline With ICD G80.0 & 34 & 189 & 1 & 0.99 & & \\
\hline Without ICD G80.0 & 25 & 203 & 0.00 & & & \\
\hline With ICD G80.1 & 0 & 15 & 1 & & & \\
\hline Without ICD G80.1 & 59 & 377 & $\begin{array}{c}1.11 \\
(0.12- \\
9.81)\end{array}$ & 0.92 & & \\
\hline With ICD G80.2 & 1 & 5 & 1 & 0.77 & & \\
\hline Without ICDD G80.2 & 58 & 387 & $\begin{array}{c}1.13 \\
(0.15- \\
12.81)\end{array}$ & & & \\
\hline
\end{tabular}


Gastroesophageal reflux disease in patients with developmental disabilities

\begin{tabular}{ccccc}
\hline With ICD G80.3 & 1 & 4 & 1 & 0.89 \\
Without ICD G80.3 & 58 & 388 & 0.92 & \\
& & & $(0.30-$ & \\
& & & $2.83)$ & \\
\hline With ICD G82.4 & 4 & 24 & 1 & 0.26 \\
& & & 0.68 & \\
Without ICD G82.4 & 55 & 368 & $1.24)$ & \\
\hline Current history of Seizure & 30 & 125 & 1.92 & 0.00 \\
& & & & \\
& & & & \\
& & & $3.22)$ &
\end{tabular}

Without current history of

\begin{tabular}{crrrrrr} 
seizure & 40 & 321 & 1 & & & \\
\hline Past history of seizure & 55 & 244 & 2.88 & 0.00 & 3.64 & 0.00 \\
& & & $(1.60-$ & & $(1.73-$ & \\
& & & $5.19)$ & & $7.63)$ &
\end{tabular}

Without Past history of

\begin{tabular}{cccccc} 
seizure & 16 & 205 & 1 & 1 \\
\hline Male & 54 & 296 & 0.63 & 0.06 & \\
& & & $(0.39-$ &
\end{tabular}

\begin{tabular}{ccccc} 
Female & 28 & 242 & 1 & \\
\hline $\begin{array}{c}\text { With involuntary } \\
\text { movements }\end{array}$ & 21 & 112 & 1.23 & 0.44 \\
& & & $(0.71-$ &
\end{tabular}

Without involuntary

$\begin{array}{llll}\text { movements } & 54 & 356 & 1\end{array}$

\begin{tabular}{ccccc}
\hline Hiperkinesis & 18 & 130 & 0.81 & 0.48 \\
& & & $(0.46-$ & \\
& & & $1.43)$ & \\
No hiperkinesis & 57 & 336 & 1 & \\
\hline anticonvulsivants use & 53 & 254 & 2.14 & 0.00
\end{tabular}


Gastroesophageal reflux disease in patients with developmental disabilities

$3.50)$

\begin{tabular}{ccccc} 
No use of convulsivants & 27 & 277 & 1 & \\
\hline Asthma medications use & 6 & 51 & 0.76 & 0.55 \\
& & & $(0.31-$ &
\end{tabular}

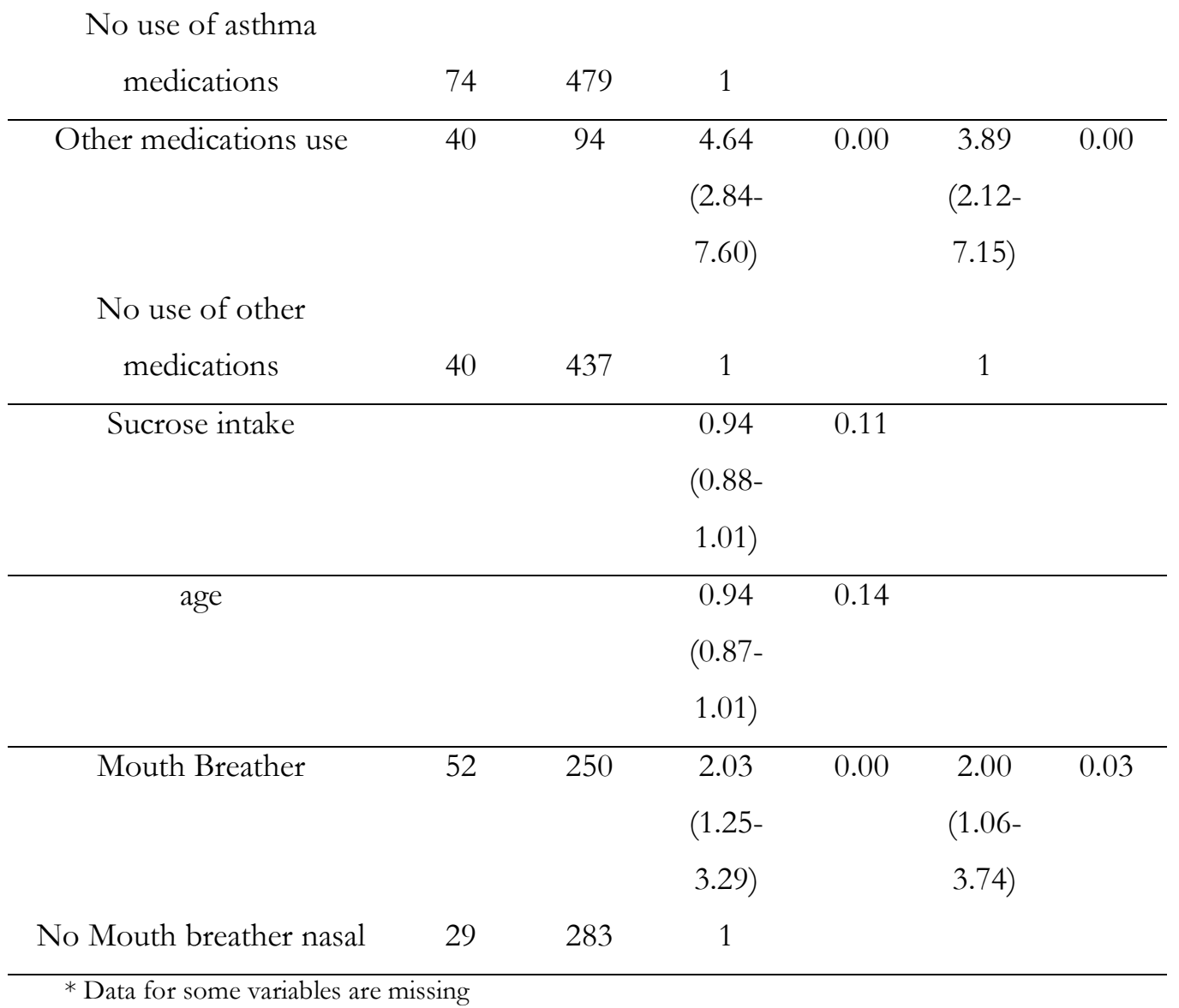

\section{DISCUSSION}

This study demonstrated that mouth breathing and the use of "other medications" were associated with gastro-esophageal reflux among individuals with developmental disabilities of the Extension Project "Dental Care for Patients with Developmental Disabilities".

The prevalence of gastroesophageal reflux was lower than that found among children with cerebral palsy in previous studies (SPIROGLOU et al., 2004) even when the data collection methodology was similar to the present study (ABANTO et al., 2014). This difference may be 
due to the total number of individuals studied, which, in our case, is much greater than the total number of cases in the two previous studies.

An association between mouth breathing and reflux was found. Some authors argue that the negative intrathoracic pressure generated by the effort to breathe (including mouth breathing) after a nocturnal apnea event will help pull the fluid out of the stomach, creating a gastroesophageal reflux (HALPERN et al., 1991; KERR et al., 1992). However, existing evidence to support this pathophysiology seems to be limited by studies and case reports (KARKOS et al., 2009). Other studies describe that respiratory problems are frequent in individuals with neurological problems and are aggravated by gastroesophageal reflux (BLACKMORE et al., 2016; KIM et al., 2017).

Gastroesophageal reflux can be more commonly seen in children with neurological disorders, particularly, cerebral palsy (BAYRON et al., 2016; KIM et al., 2017). Valproic acid, gabapentin, topiramate or phenobarbital can reduce the level of consciousness and harm swallowing (JIMENEZ et al., 2010), especially valproic acid (PENAGINI et al., 2015). In rats the Valproic acid exposure during pregnancy decreased the thickness of tunica mucosa and tunica muscularis in the stomach and ileum and decreased motility in the Gastro Intestinal tract was also observed in the animals' offspring prenatally exposed to VPA (KIM et al., 2017).

Gastroesophageal reflux is one of the main causes of non-epileptic paroxysmal events (BAYRAN et al., 2016). In relation to the association with seizures occurring in the past, as observed in this study, it should be considered that gastroesophageal reflux may mimic seizures and may be confused with epilepsy. Induction of an episode is the preferred method for confirming the non-epileptic nature of seizures by video-electroencephalogram examination (MENESES, 2002). This coincidence between reflux and non-epileptic paroxysmal events may complicate the treatment of patients, imitating refractory seizures (OBEID; MIKATI, 2007). In patients with acute non-epileptic spasms, sleep disturbances, lip weakness, salivation, flexor spasms, headache, and myoclonus have been observed to improve after treatment of gastroesophageal reflux, especially among patients with developmental disorders. In addition, the condition of patients with flexor spasms, headache, and myoclonus improved without recurrence during the follow-up period after adoption of reflux treatment. These findings support the view that non-epileptic paroxysmal spasms may actually originate from gastroesophageal reflux (BAYRAM et al., 2015). Abnormal movement that occurs during reflux may be a consequence of a mechanism that protects the passage of air from the regurgitated material or to relieve abdominal discomfort caused by acid reflux. The authors finally emphasize that children who are admitted to medical services as having epilepsy should be evaluated for gastroesophageal reflux. 
It was expected, in this study, that gastroesophageal reflux was associated with cerebral palsy as previously reported, especially in the spastic quadriplegic (ROTTA et al., 1983; FURKIM et al., 2003; ARAUJO et al., 2012; PEREIRA et al., 2016) but this result was not confirmed. It was not confirmed neither with the diagnosis of spastic tetraplegia (G 82.4), which is the second most frequent diagnosis among users of this dental service after diagnosis of spastic quadriplegic cerebral palsy (G80.0).

The study did not reveal a relation between gastroesophageal reflux and sex, as did the study carried out by a previous study (KIM et al., 2017). Only a review showed association with males (CAFAROTI et al., 2014). Similarly, there was no correlation with age, agitated or aggressive behaviors, and involuntary movement (GÖSSLER et al., 2007), which was not proved by the results presented here.

This study has limitations. The dental team does not have access to the diagnosis of gastroesophageal reflux directly from the medical team, but rather through reports from parents or caregivers. This happens with other independent variables that were used in this study. Despite this, parents and caregivers are the most qualified individuals to report to the health teams the symptoms and characteristics of their children and therefore, medical professionals must respond to the judgment of abnormalities in the caregivers' behaviors, even if typical symptoms are lacking (GÖSSLER et al., 2007). Another limitation is the small possibility of causal inference, typical of a cross-sectional study.

This study allowed the undergraduate dentistry student to study gastroesophageal reflux among a specific population. From this investigation, this student can propose a dental treatment plan appropriate to the profile of his patient promoting his oral health and general health. By publishing these results, other similar projects and programs can compare their results with the present study and add new information aimed at the development of knowledge and healthy practices.

\section{CONCLUSIONS}

The prevalence of gastroesophageal reflux was small when compared to other groups with cerebral palsy in Brazil. Be a mouth breather, consuming "other medications", and having a previous history of seizures are factors associated with gastroesophageal reflux, among individuals with developmental disabilities.

Identifying and understanding the factors that can predict the occurrence of reflux in patients with developmental disorders are particularly important to identify groups with a higher 
chance of having this condition and to establish the best treatment approach. On the other hand, the dental team can assist the medical and speech therapy teams to diagnose gastroesophageal reflux through detectable signs in the oral cavity.

\section{REFERENCES}

ABANTO, J.; SHITISUKA, C.; MURAKAMI, C; CIAMPONI, A.L.; RAGGIO, D.P.; BONECKER, M. Associated factors to erosive tooth wear and its impact on quality of life in children with cerebral palsy. Special Care in Dentistry, v.34, n.6, p.278-285, Apr. 2014.

ARAÚJO, L.A.; SILVA, L.R.; MENDES, F.A.A. Digestive tract neural control and gastrointestinal disorders in cerebral palsy. Jornal de Pediatria, v.88, n.6, p.455-464, Nov. Dec. 2012.

BAYRAM, A.K.; CANPOLAT, M.; KARACABEY, N.; GUMUS, H.; KUMANDAS, S.; DOG ${ }^{\sim} A N A Y$, S.; ARSLAN, D.; PER H. Misdiagnosis of gastro-esophageal reflux disease as epileptic seizures in children. Brain \& Development, v.38, n.3, p.274-279, Mar. 2016.

BLACKMORE, A.M.; BEAR, N.; BLAIR, E.; GIBSON, N.; JALLA, C.; LANGDON, K.; MOSHOVIS, L.; STEER, K.; WILSON, A.C. Factors associated with illness in children and young adults with cerebral palsy. The Journal of Pediatrics, v. 168, n.1, p.151-157, Oct. 2016.

BRAUNA, A.P.S.V.; ABREU, M.H.N.G.; RESENDE, V.L.S.; CASTILHO, L.S. Risk factors for dental caries in children with developmental disabilities. Brazillian Oral Research, v. 30, n.1, p.79-84, Jan. 2016.

CAFAROTTI, A.; BASCIETTO, C.; SALVATORE, R.; BREDA, L.; CHIARELLI, F.; PIERNICOLA P. A 6-month-old boy with uncontrollable dystonic posture of the neck. Sandifer syndrome. Pediatric Annals, v.43, n.1, p. 17-19, Jan. 2014.

FURKIM, A.M.; BEHLAU, M.S.; WECKX, L.L.M. Avaliação clínica e videofluoroscópica da deglutição em crianças com paralisia cerebral Consistência e tempo de deglutição em paralisia cerebral tetraparética espástica. Arquivos de Neuropsiquiatria, v.61, n.3, p.611-616, Set. 2003.

GÖSSLER, A.; SCHALAMON, J.; HUBER-ZEYRINGER, A.; HÖLLWARTH, M. Gastroesophageal reflux and behavior in neurologically impaired children. Journal Of Pediatric Surgery, v. 42, n. 2, p.1486-1490, Sept. 2007.

HALPERN, L.M.; JOLLEY, S.G.; TUNELL, W.P.; JOHNSON, D.G.; STERLING, C.E. The mean duration of gastroesophageal reflux during sleep as an indicator of respiratory symptoms from gastroesophageal reflux in children. Journal of Pediatric Surgery, v.26, n.6, p. 686-690, June 1991.

HSU, C.K.; LAI, C.C.; WUANG, K.; CHEN L. Risk of lung cancer in patients with gastroesophageal reflux disease: a population-based cohort study. Peer J 4:e2753, Dec. 2016.

HUYNH, N.T.; EMAMI, E.; HELMAN, J.I.; CHERVIN, R.D. Interactions between sleep disorders and oral diseases. Oral Diseases, v. 20, n. 3, p.236-245, Apr. 2014. 
JIMENEZ, D.G.; MARTIN, J.J.D.; GARCÍA, B.; JIMÉNEZ, T. Patología gastrointestinal em niños com parálisis cerebral infantil y otras discapacidades neurológicas. Anales De Pediatría, v. 73, n.6, p.361-366, Dec. 2010.

KARKOS, P.D.; LEONG, S.C.; BENTON, J.; SASTRY, A.; ASSIMAKOPOULOS, D.A.; ISSING, W.J. Reflux and sleeping disorders: a systematic review. The Journal Of Laryngology Otology, v.123, n. 4, p.372-374, Apr. 2009.

KERR, P.; SHOENUT, J.P.; MILLAR, T.; BUCKLE, P.; KRYGER, M.H. Nasal CPAP reduces gastro-esophageal reflux in obstructive sleep apnea syndrome. Chest, v.101, n. 6, p.1539-1544, June, 1992.

KIM, S.; KOH, H.; LEE, J.S. Gastro-esophageal Reflux in Neurologically impaired children: what are the risk factors? Gut And Liver, v. 11, p. 232-236, 2017.

MENEZES, M.A.S. Distúrbios paroxísticos não-epilépticos. Jornal De Pediatria, v.78, n.2, p.73-88, Mar.2002.

MENGATTO, C.M.; DALBERTO, C.S.; SHEREEN, B.; BARROS, S.G.S. Association between sleep bruxism and gastroesophageal reflux disease. J Prosthet Dent, v.110, n.5, p.349-55, Nov. 2013.

OBEID, M.; MIKATI MA. Expanding spectrum of paroxysmal events in children: potential mimickers of epilepsy. Pediatric Neurology, v.37, n.5, p.309-16, Nov.2007.

PENAGINI, F.; MAMELI, C.; FABIANO, V.; BRUNET'TI, D.; DILILLO, D.; ZUCCOTTI, G.V. Dietary Intakes and Nutritional Issues in Neurologically Impaired Children. Nutrientsv.7, n.11, p.9400-9415, Nov. 2015.

PEREIRA, A.; MOREIRA, T.; LOPES, S.; NUNES, A.R.; MAGALHÃES, P.; FUENTES, S.; REOYO, N.; NÚÑES, J.C.; ROSÁRIO, P. My Child has Cerebral Palsy": Parental Involvement and Children's School Engagement. Frontiers In Psycology, v. 7, p.1-13, Nov. 2016.

ROTTA, N.T.; DRACHLER, M.L.; VAITSES, V.D.C.; OHLWEILER, L.; LAGO, I.S. Paralisia cerebral: estudo de 100 casos. Revista HCPA, v.78, n.1, p.113-116, July/Aug.1983.

SPIROGLOU, K.; XINIAS, I.; KARATZAS, N.; KARATZA, E.; ARSOS, G.; PANTELIADIS, C. Gastric emptying in children with cerebral palsy and gastroesophageal reflux. Pediatric Neurology, v. 31, n.3, p. 177-182, Sept. 2004.

TRINICK, R.; JOHNSTON, N.; DALZELL, A. M.; MCNAMARA, P. S. Reflux aspiration in children with neurodisability: a significant problem, but can we measure it? Journal of Pediatric Surgery, v. 47, p. 291-298, 2012.

Recebido em: 27/02/2020

Aceito em: $11 / 08 / 2020$ 